Teaching basic theological doctrines on love, marriage and religiosity: Reconciling the church's teaching and the perspectives of Catholic teens

Cañete, Jonathan James O. $\triangle$

De La Salle University, Philippines (jonathan_james_canete@dlsu.edu.ph)

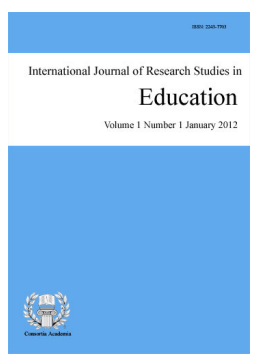

ISSN: 2243-7703 Online ISSN: 2243-7711

\title{
Abstract
}

Issues on love, marriage, and religiosity are some of the widely debated topics in the current time. The Church has her own sets of moral precepts on the aforementioned topics that seemingly have a conflict with the beliefs and sets of values of the contemporary man especially the young. This conflict of belief creates a shaft or a point of tension between the Church and the young that would often end up into catastrophic and lurid outcomes. This study would lay down the notion of the young represented by selected students of Pasig Catholic College on the topics of love, marriage, and religiosity and determine whether their understanding on those topics is in line with what the Church teaches. After the point of comparison has been drawn and after determining whether these students qualify as part of the liberal wing of the Christian faith recommendations were proposed for the Church to not just administer to the spiritual needs of the young but to live the principle of cura personalis in the spirit of synodality.

Keywords: Catholicity; conservative; liberal; love; marriage 


\section{Teaching basic theological doctrines on love, marriage and religiosity: Reconciling the church's teaching and the perspectives of Catholic teens}

\section{Introduction}

There is this ageless proverb that says that there is only one thing permanent in this world, and that is change. Essentially, it is the only constant thing in this world (Aparta, 2015). The evidence of change in the course of the world is expressed in nature's seasonal transition, the condition of the climate, the advancement of science and technology, the fast facing movement of modernity, and the inevitable motion of time and space. All these things are expressions of change. The presence of change with its various expressions is undeniable that all are affected by it. Hence, Jason Bittel (2015) argued that change, with all its expressions or manifestations in reality, "affects the way creatures interact with each other," especially on the level of the human person. Change affects humanity in various ways in reality. One can better understand the effects of change by looking at its presence in the movement of valuative knowledge. The revolution that change brought in the sets of moral values that humanity uphold creates division and conflict; this revolution brings in new sets of moral values that alter the conventional, objective, and more universal moral values that shape and form the identity of society. Thus, the tension is between the new and traditional moral values as well as the contention on how the two have effects on the integral scale of humanity in particular and society in general (Crossroads, 2018).

One of the many alterations that change had brought into the moral fiber of society is on the field of gender and love in relation with homosexual marriage. Many are affected by these elements, but the most affected sector of society is the youth. The study conducted by Hardgrove, Pells, Boyden, and Dornan (2014) for the United Nations exposes that young people are susceptible to different factors that surround their existence. Factors such as family, friends, religion, school, and others comprising their social sphere deeply affect their world; the social paradigm deconstructs the personal cosmic world of the person. Change, as an inevitable force in the world, is very much evident both in the level of the social and private spheres, intertwiningly affecting each other in a kind of movement that brings a certain quality of existence. By citing the work of Morrow (2013), Hardgrove, Pells, Boyden, and Dornan observed that the effect of change in society, particularly among the youth, "is often gradually involving numerous shifts" (Hardgrove et al., 2014; Del Castillo, 2016) of perspective in life. In this regard, the alterations that change has brought into the moral fibers of society in terms of issues on love, gender, and marriage affect the way young people conduct themselves and challenges the conventional sets of moral values and even their inherent moral values brought by religion. This thought seemingly creates an atmosphere of independence of one's existence from the influence of existing conventional moral values that objectively shapes one's moral concept; the self is not anymore in utter confluence with those values but forms its own and self-determined ethical canon. This moral canon, as observed, is most of the time in conflict, if not incongruent, with what is conventional.

Social thinkers recognized this phenomenon as moral relativism. The doctrine of moral relativism states that there is no absolute truth of an inevitable reality or thing; there is no universal objective truth. Instead, there is only the multiplicity of truths depending on the interpretation. It is, therefore, how reality appears before the person that determines the way of understanding and the production of the truth of the same reality. Take, for example, the value of $\mathrm{x}$ is "dependent on and co-varies with some underlying, independent variable $\mathrm{y}$ " (Baghramian, Baghramian, \& Adam, 2019). In this regard, "x" represents a phenomenon (e.g., ethical norms, values, epistemic norms, aesthetical norms, experiences, judgment, and the world) which consists a reality, and "y" here, in this case, refers to the human person as the independent variable that comprehends and analyzes the reality of " $x$ ". The human person in the doctrine of relativism is the basis of that which is something real to a given fact. Relativism takes away in moral norms its inherent objectivity and universality, centering its normativity based on the perception of the person as moral normality. Because of the negative tendency of moral

52 Consortia Academia Publishing (A partner of Network of Professional Researchers and Educators) 
relativity, the Supreme Pontiff John Paul II (1993) in Veritatis Splendor condemns the values of moral relativism and upholds the objectivity and universality of ethical norms as one of the expressions of nature (natural law) that sets the order in the social sphere of the entire cosmos; universal-objective moral standards adhere to the intrinsic value and purpose behind the reason being of creation. This simply means that nature itself has reasonability behind its existence ordained by its creator; the creator wills that everything came to be, and everything ought to be something or someone in accord with its respective end. Furthermore, it is by being what it should be that the entire creation, with its fundamental purpose apparent in reality, could speak of God, its creator, whose mind sets forth the original order in the whole nature. It is only by conforming one's being with one's own and respective existential end that he/she, with his/her being, could praise God (Cf. Ps19:1).

Following this line of thinking and the condemnation of John Paul II, it seems that moral relativism poses a significant threat in the natural essence of reality; it distorts the order that God had ordained in creation. Though relativism is a product of intellectual abstraction of the human person, one cannot take away the distortion it can create on the same reality that it wishes to understand. Though the distortion is intellectual, it has, in itself, a corresponding effect in the way creation is to be treated. On the level of morality, relativism affects the way people act and interact with fellow human beings, nature, non-human animals, and the self. Moral relativism undermines the appropriateness of interaction as determined by nature as normative. In other words, moral relativism employs a multiplicity of approaches towards how others, the environment, non-human animals, and the self are to be treated depending on the ethical parameters set by the person. This does not necessarily follow patterning one's moral precepts to what is objective and normative as per natural law. This, in itself, creates a moral discord for the possibility that the moral teachings of the person may not be in congruence with what the natural law mandated. The person will end up treating others the way one would want them to be treated. This, by the nature of the act, is deemed problematic for the possibility of abuse would not be avoided (Boghossian, 2011). Because of the possible existence of violence in the social sphere, the natural moral fabric which was purposively ordained to establish relationship and unity among individuals is distorted and its purpose becomes a lucid dream.

One of the concepts of moral issues that had been affected by change is the moral issue of love, family, marriage, and religiosity. Talking about this contemporary issue, the opinion of many varies and signifies the division of cultural standpoint. Society, concerning this issue, is divided into two primary caste - the conservative and the liberal. In this case, many would identify the Church under the conservative wing on matters of doctrines, morals, and worship. Dean Kelley, in Why Conservative Churches Are Growing, enumerated three predominant traits of a conservative Church - absolutism, conformism, and fanaticism (Kelly, 1977, pp. 79-84). A traditional Church employs absolute conformity through steadfast adherence to its doctrinal teachings and liturgical practices seen in the followers' lifestyle. Here, faithful adherence to the Church's doctrinal teachings and ceremonial practices is the very basis of religiosity and propriety. This attitude suggests conservatism. While those who do not strictly follow, in one way or another, the directions of the Church or having their alterations on the Church's doctrines, moral norms, and liturgical practices based on the contemporary issues are regarded under the liberal wing. In context, the Church has her own doctrinal and moral stance concerning the subject of love, marriage, and religiosity, therefore asking the believers to understand it based on how the Church comprehends it, thus following the precept that the Church ordains. Then again, those who have other interpretations concerning the teaching are considered liberal members. Daniel Bush (2019) mentioned that open-minded members of the Church tend to align their presentations on the Church teachings based on what the contemporary situation is asking, it is an attempt to make relevant the Church teachings in the modern times. Moreover, among all who are considered liberal, the youth perhaps aces the list.

The young ones, because they are products of their generation, know the situation where they are living and know how to make faith relevant in their own context. The young generations, who would present and amalgamate the conventional and conservative teachings of the Church to the ever dynamic and changing context of the modern world, are treated by many conservative Church congregants as liberal congregants. Joseph Alpert (2016) argued that conservative ones tend to be ideal while the liberal ones are practical overseers. 
However, the assertiveness of both the liberal and the conservative on what they believe in is the one thing that seems to unite both parties. Though both of them have this tendency to be confident, the kind of brazenness varies. The conservatives' sort of assertion is through the play of ideas while the liberals' assertiveness is seen in the domain of praxis; conservatives assert through ideas while liberals assert though their way of life. Therefore, there exists a tension on this matter between the two.

This study, therefore, is an attempt to understand whether such tension exists between the personal belief and interpretation of selected Grade 12 Catholic students of Pasig Catholic College regarding the Church's teachings on love, marriage, and homosexual relationship to the prescription of the Church. Moreover, this is to assess if their beliefs are in line with the precepts of the Church or belonging to the progressive liberal wing of Christianity, therefore considering them as antichurch by having a progressive set of Christian belief. Can one consider them as someone who is against the teachings of the Church or do, they just give the Church another way of looking at the faith using contemporary lenses, practicing their Catholicity beyond the restrictions posed by the immutable doctrines? Does this mean that they cannot be considered Catholics or even followers of the ways of Jesus? Is being liberal on the issue of love, marriage, family, and homosexual relationship against the norm of Catholicism? Can one still be considered a Catholic and a believer of the way even though one has a liberal set of moral standards and a belvedere of contemporary Catholic doctrines? Is "change" in the ethical standards hideous or is it an opportunity for revitalizing the faith and making Catholicity relevant in the contemporary era through the very appropriation of the faithful, most especially the youth of the teaching of the Church, in their modern ways and means?

\section{Methodology}

\subsection{Research design}

This research measures the (1) perception of selected Grade 12 students of Pasig Catholic College on preexisting ecclesial norms on love, marriage, and religiosity, (2) illustrates their beliefs as conservative or liberal, and (3) determines if such beliefs complements or endangers the Church. On the other hand, while maintaining its quantitative aspect this study also has a qualitative element. Cultural texts and productions were used to supply sufficient and strong justification for the quantitative result.

\subsection{Respondents}

Since the study focuses on the Catholic denomination, homogenous purposive sampling was used and determined the specific number of respondents using Krejcie and Morgan's (1970) table for determining sample size from a given population. Since there is a total of 473 Grade 12 Catholic students from Pasig Catholic College, 214 respondents were selected and surveyed. Part of the qualification in determining the samples are the longevity of their stay in the institution, which would speak of the level of religious formation they received. The researcher then divided the sample fairly among the different tracks and strands using stratified random sampling to ensure a well distribution of data. The respondents, then, were selected in their respective sections by means of convenience random sampling method wherein the class presidents of each section identified the respondents without the adequate knowledge of the researcher.

\subsection{Research instrument}

The researcher initially came up with 24 sitations based on published documents related to the study as the research tool in measuring and knowing the moral stance of the respondents with regards to the issue being exposed. The situations were based on the works of St. John Paul II, primarily the documents Redemptor Hominis (1979), Gratissimam Sane (1994), and Familiaris Consortio (1981); Benedict XVI's Deus Caritas Est (2005); Francis' Amoris Laetitia (2015); and lastly, the survey questions from David William (2003) of the University of Michigan entitled Commitment. It is good to note that there are situations that denote precisely the

54 Consortia Academia Publishing (A partner of Network of Professional Researchers and Educators) 
Teaching basic theological doctrines: Reconciling the church's teaching and the perspectives of Catholic teens opposite of what its source is conveying. These distracter situations are vital and are deemed necessary in this study for they aid in determining the moral stance of the respondents concerning the issue being discussed.

The initial research instrument was categorized under three variables - Love, Marriage, and Religiosity. The initial roster of situations in the research instrument were evaluated by Subject-matter Experts (SMEs) who have "adequate skills, knowledge, and experience in a particular field" (Hopkins \& Unger, 2017) for validation. The SMEs were selected from the field of Philosophy, Theology, Psychology, and Psychometrics. The SMEs' evaluation proves that the items of the initial research instruments are reliable and accepted, having a grand mean score of $\bar{x}=2.95$, thus very appropriate to be administered to the determined respondents. Hence, this gave the researcher the green light to proceed to the next stage of the study, which is the development of the survey form. To double-check the reliability of the official canon of situations, the researchers ran through the result using Cronbach's Alpha Coefficient. The result showed that it was aligned with the result of the SMEs evaluation on the reliability of the situations.

\subsection{Statistical treatment}

The survey form retains its 24-item number belonging to three categories and is in the four-point Likert scale form that would measure the acceptability of the respondents on the different situations. After the form had been formalized, the researcher administered the survey test. There were two statistical treatments used in this study. The first one was descriptive statistical analyses, while the second one was the Pearson Correlation Analysis. Descriptive Analysis was used in treating and describing the basic features of the data (Trochim, 2020). In the context of this research, descriptive analysis was deemed essential for it to show the result as to what scale the response of the students fell. On one hand, Pearson Correlation Analysis is a proper tool that would measure if there is a significant relationship between the variables (University of Minnesota, 2020) of love, marriage, and religiosity. Pearson Correlation Analysis would determine if the sense of religiosity of the respondents has a significant relationship with their notion of love and marriage, which would give the reader an overview of their moral stance on the aforementioned issues. At this point, the researcher still maintains that there is no significant relationship between each variable.

\section{Results}

The tables below show the result and statistical interpretation of the respondents' answer with regard the survey that was given to them. However, there is a problem as regards to the proper tool to be used in interpreting the Descriptive Statistical Data. Hence, The Levels of Conservatism and Liberalism Scale (LCLS) was developed.

\section{Table 1}

Levels of Conservatism and Liberalism Scale

\begin{tabular}{cll}
\hline Numerical Value & \multicolumn{1}{c}{ Acceptability Level } & \multicolumn{1}{c}{ Level of Conservatism or Liberalism } \\
\hline $1-1.49$ & Unacceptable & Religiously Conservative \\
$1.50-2.49$ & Slightly Unacceptable & Slightly Conservative \\
$2.50-3.49$ & Slightly Acceptable & Slightly Liberal \\
$3.50-4.00$ & Acceptable & Religiously Liberal \\
\hline
\end{tabular}

The LCLS table gives the level of acceptability and level of religious conservatism or liberalism of the respondents using the numerical value of the given mean score. In context, this will help the researcher determine whether the respondents had a liberal and conservative perception on love, marriage, and religiosity based on their response to the research instrument that was given to them. The table is statistically operational with the use of the four-point measurement scale. 
Cañete, J. J. O.

Table 2

Descriptive statistical analysis of variables

\begin{tabular}{lcccc}
\hline \multicolumn{1}{c}{ Statistics } & Love & Marriage & Religiosity & Total \\
\hline $\mathrm{N}$ & 214 & 214 & 214 & 214 \\
Mean & 2.86 & 2.92 & 3.10 & 2.98 \\
Median & 2.86 & 2.86 & 3.10 & 3.00 \\
Standard Deviation & 0.407 & 0.400 & 0.435 & 0.330 \\
Minimum & 1.00 & 1.71 & 1.00 & 1.38 \\
Maximum & 4.00 & 4.00 & 4.00 & 4.00 \\
Skewness & -0.365 & 0.104 & -0.583 & -0.519 \\
Kurtosis & 1.25 & -0.0788 & 1.75 & 2.45 \\
\hline
\end{tabular}

Table 2 Shows the perception of selected Catholic Grade 12 students on matters of love, marriage, and religiosity, which comprises the variables of this study. The variable love has an overall mean of $\bar{x}=2.86$ with a standard deviation of 0.407 , signifying that the respondents, plotting the overall mean result to table 1 , would slightly accept the liberal notion of love. On the other hand, the variable marriage has an overall mean of $\bar{x}=$ 2.92 with a standard deviation of 0.400 signifying that the respondents, like in the previous case, would have a slightly liberal concept of love. The variable religiosity, on the other hand, has an overall mean of $\bar{x}=3.10$ with a standard deviation of 0.435 , signifying a slightly progressive approach to religiosity. Furthermore, the overall average of the three variables received a mean of $\bar{x}=2.98$, with a standard deviation of 0 . 330.This would simply mean that, with regard the issues on love, marriage, and religiosity, the respondents would have a slightly liberal stance and disposition. Having been illustrated the statistical descriptive of the result, the table below shows the result of the Pearson Correlation Analysis that would give a further sense of the possibility of any significant or insignificant relationship between the identified variables.

Table 3

Pearson correlation analysis

\begin{tabular}{llccc}
\hline \multicolumn{1}{c}{ Items } & \multicolumn{1}{c}{ Statistics } & Love & Marriage & Religiosity \\
\hline Ave. Love & Pearson's $\mathrm{r}$ & - & & \\
& $p$-value & - & & \\
Ave. Marriage & $\mathrm{N}$ & - & & \\
& Pearson's $\mathrm{r}$ & $0.265^{* * *}$ & & \\
& $p$-value & $<.001$ & & \\
Ave. Religiosity & $\mathrm{N}$ & 214 & & - \\
& Pearson's r & $0.481^{* * *}$ & $0.471^{* * *}$ & - \\
& $p$-value & $<.001$ & $<.001$ & - \\
\hline Note. ${ }^{*} p<.05,{ }^{* *} p<.01, * * * p<.001$. & 214 & 214 &
\end{tabular}

Table 3 shows the variables of Religiosity and Love got a computed r-value of 0.481 , which shows a moderate positive relationship. Likewise, it got a calculated $p$-value of $<.001$, rejecting the null hypothesis. Hence, there is a significant relationship between the practice of religiosity of the respondents with their notion of love. On the other hand, the same table also shows the variables of Religiosity and Marriage got a computed r-value of 0.471 , which then again indicates a moderate positive relationship. Equally, it got a calculated $p$-value of $<.001$, rejecting the null hypothesis. Therefore, there is a significant relationship between the religiosity of the respondents with their understanding of marriage.

This speaks about the existence of a significant relationship between the independent variable and the two dependent variables. Meaning to say, one variable speaks of the nature of the other. In this case, the notion of the respondents on love and marriage speaks and qualitatively describes the level of the religious temperament of the respondents. One can now proceed to the discussion on how these results would determine the moral stance or concept of the respondent with regard homosexual marriage. 


\section{Discussions}

The result from the two statistical analyses explicitly infer that the Catholic Grade 12 students of Pasig Catholic College have a strong sense of Catholic faith, and the centrality of God plays a pivotal role in their life. However, their perception of love and marriage in relation to the homosexual union is quite contrary to what the Catholic Church teaches. Based on the descriptive result, the respondents do have a liberal and modern notion of love and marriage. Having garnered a mean value (love $=2.86$, marriage $=2.92)$ that falls on the liberal wing, the respondents do have a different moral stance regarding love and marriage compared with what the Catholic Church has, for the notion of the respondents regarding the issue at hand leads to the approval of homosexual relationship leading to marriage as an acceptable moral norm.

What is essential for the respondents is to have a moral standard on love and marriage that does not restrict, limit, or even condemn the person for who he/she really is; it is accepting and loving the person for who he/she really is, no matter the circumstances are. Love is not all about gender as marriage is not only between a biological man and woman as long as God is at the center of the relationship. In this sense, the centrality of God possesses an issue here. According to the Dogmatic Constitution De Fide Catholica of the 1st Vatical Council (1870, par.1), God would be in his Church and the Church is in God unifying the people to and with Him (Lumen Gentium, 1964). Two Church Councils exemplify the Catholic Church as the portato (bearer) of God's presence. Therefore, God is not present in things outside the Church. In this case, any concept of love, marriage, and family, no matter what it may be, if they are outside on what the Church mandates, is not of God. Therefore, the belief of the respondents concerning loving someone as long as God is at the center and not the Church is a deceptive assertion that undermines the authority of the Church.

However, what is more interesting is that the analysis also shows that in the midst of having a liberal notion on love, marriage, and the approbation on the homosexual relationship, the respondents themselves are proven religious, having garnered a mean value of 3.10. They have illustrated based on the result that God and faith are important in their daily life. Their Catholic identity is fundamental in their existence. However, religion is not everything; it is essential, but it is not the only reality that matters, what matters is the belief on God (Council of Europe, 2020). This in itself is revolutionary for there exists the principle of dualism between the religious identity of the respondents, compelling them to act according to the dictates and the mandates of Church and their personal stance on love, marriage, and religiosity. There are polarities and conflicts of moral standards-the moral standard of the Church with the personal moral position of the respondents. Indeed, dualism is very evident.

\subsection{Moral dualism}

Dualism is traditionally defined as the contradiction between two or more principles; it could also mean the amalgamation of opposites. Dualism could be seen in the metaphysics of body and soul or in the sphere of theology, especially on the issues between good and evil (Stanford, 2016). The dualism that the respondents exhibited based on the statistical analysis is a moral one.

Moral dualism exists because of the coercion between the morality of the person and the ubiquitous moral standard of the Church or of a specific ruling class. The Contribution of Religion to Social Work of the scholar Reinhold Niebuhr (1930) illustrated that the leading cause of moral dualism is no other than the despotic state of the social, moral norm. He argued that while maintaining social order, religious, ethical standards collaterally damage and condemn individual members of society; it holds, at one point, an impression of social injustice for the sake of what is natural and deemed acceptable. The sense of social injustice stems from the feeling of alienation that some people experience that disables them in fully exercising their rights and their identity; they act and conduct themselves based on the dictates of the ruling class as to what is normative and so to be the kind of person that is acceptable and morally dignified in accordance to their designs. This simply means that the social identity of a person is already predetermined and should be filled in by the person himself/herself through 
appropriating one's very identity to the process of their predetermined self-becoming. In other words, moral dualism limits a person's self-becoming. He is deprived of the opportunity to be the kind of person of his own choosing, one type of person after his own image.

Because the ruling class imposes its moral standards against the moral standard of the person, one cannot take away the possibility of moral coercion. Moral coercion is a condition whereby the person insists his/her own moral belief against what is morally normative based on the standard of the Church or of a specific ruling class. This coercion would lead to moral relativism. In this case, the moral standard of the respondents on love and marriage geared toward the possibility of homosexual relationships appreciates the personhood of a particular member of society - the LGBTQ. However, with regard to the same variables, the Church is clear about her doctrines, and her doctrinal position cannot be otherwise; there is no middle ground. Though there are efforts in opening an ecumenical dialogue with a member of this social class, the Church's position still remains the same. Therefore, for the Church, the position of the respondents, though may seem biblically-based like "loving one's neighbor as one loves oneself," their openness to the same-sex union as expressed in the mean value of their answers for situations under the category of love and marriage, is in itself an anathema or an unaccepted set of moral standards that demean the beauty of love, sex, marriage, and the family which has a God-ordained purpose.

Hence, the respondents who are born Catholics and currently are studying in a Catholic school with adequate Catholic formation have sets of beliefs that are against their faith. They have a liberal set of moral standards on the aforementioned topics that challenge the conventional stance of the Church. For the Church, it is really inappropriate to have such openness to the possibility of homosexual union. But is there really a problem with being open to that belief? Are the respondents less Catholic by having such liberal moral standards or are they making sense of the ecclesial teachings themselves, making it in dialogue to the contemporary world and to people who are being cast out simply because they are unique? Surprisingly as it may seem, the result also shows that the respondents themselves have a deep sense of their faith. However, because of their belief, they inevitably fall on the liberal wing of Catholicism. They are not outside the Church but very much part of her. That is why it is good to know the reason for this moral dualism between them and the Church. It is good to look at how the Church defines and understands the concept of love, marriage, and homosexuality as well as homosexual union and later on see if there is really any point of contradiction between what the Church says and what the respondents believe.

\subsection{Defining love: Man created to love}

In the midst of a pluralistic definition of love that society develops, it is perhaps in the epistle of John that one can really understand the meaning of love. He explicitly states the very definition of love that the Catholic tradition upholds. For the evangelist, "God is love, and he who abides in love abides in God, and God abides in him" (1 Jn. 4:16). Here, John is conveying an outstanding theological exposition on love and is linking it to the very identity of God. His theological commentary "expresses with remarkable clarity the heart of the Christian faith: the Christian image of God and the resulting image of mankind and its destiny" (Benedict XVI, 2005). The evangelist proposes an image of God that is love. In other words, love is not just an attribute of God nor a simple emotion nor a product of a chemical change in man; it is God Himself.

The semantics clearly convey that when using the linking verb "is," one is not just linking a noun with an adjective; instead, one is describing or better yet defining the nature of that noun. In this case, by saying that "God is love," one is determining who God is and illustrating His very essence. If God is love, then all that proceeds from God are in full accord with His nature. Meaning to say, everything that comes from God speaks of his essence as love and the very reason behind the very activity of God. In this case, creation as the result of God's activity speaks of the essence that God has in Himself. St. Thomas Aquinas in Summa Theologica (1911) made it clear that God did not create only to produce, but when one says "that in Him there is a procession of love, one shows that God produces creatures not because He needed them, nor because of any other extrinsic

58 Consortia Academia Publishing (A partner of Network of Professional Researchers and Educators) 
Teaching basic theological doctrines: Reconciling the church's teaching and the perspectives of Catholic teens

reason but on account of the love" (170) that He has and He is Himself. God creates because He simply loves, and $\mathrm{He}$ cannot but love because that is what He is, for "He cannot deny Himself" (2 Timothy 2:13). The entire creation, therefore, is an expression of God's outpouring of Himself. As an expression of the essence of God, creation in its nature expresses back this same essence by which they were made. In other words, creation radiates the essence of God by magnifying it in their state of nature and existence (Piper, 1987). It is through this that creation sings of the glory of the Lord (Hill, 1996). Nevertheless, the focal point of God's expression is seen in the human person.

Among all created beings that God had made, the human person has a special place in the entire creation. He is created in the very image and likeness of God. It is only the human person that was created after the creator's image. Man, therefore, partakes in the divine nature of God (2 Pt 1:4; cf. CCC, 1992, par. 460). Meaning to say, in this spirit, God's essence as love is also man's essence. Being created in this unique way is not a mere privilege, but it entails a response to participate in God's essence; partaking in His divine nature means partaking oneself in the very essence of God who is love.

This, in itself, becomes man's fundamental vocation. One might ask how a man can participate in God's essence? How can he/she respond to the call of his/her own essence? It is good to note that movement and characteristics of love, in this regard, are extrinsic of the person; the direction of love is toward the other, not on oneself. Therefore, love leads to Caritas. Equally, it is said that creation, in their very existence and nature, radiates the essence of God. In man's case, it is through the spirit of Caritas that he/she fulfills the demands of his primary vocation in manifesting the essence of God in his/her own existence and nature. It is by loving others in the spirit of charity - the way God loves — could a man be true to his own nature and essence for "man cannot live without love. He remains a being that is incomprehensible for himself; his life is senseless if love is not revealed to him, if he does not encounter love, if he does not experience it and make it his own, if he does not participate intimately in it" (John Paul II, 1979, par. 10). He/she is created in the very image and likeness of God, who loves Himself. Therefore, it is natural for man to do things in accordance with his nature to love as his creator loves; to outpour oneself to the other regardless of what one might receive. This is the spirit of Caritas.

Caritas as love is directed towards the other person, not primarily on oneself. Since it is a kind of love that is geared toward the other person, it shuns, therefore, every selfish act and tendency of love that makes the richness of its very self as well as the richness of its origin tawdry and ephemeral (Francis, 2016); though love is a personalistic pursuit that enriches the human person, its very nature cannot just be personalistic for it is other-centered. This is the centerpiece of Jesus' commandment on love. Loving God, above all else (Mk. 12:30), is to radiate His essence of love in and through man's life; that is by means of loving others the way he loves himself (Mk. 12:31). Here, love is a personalistic journey of loving God through the very depersonalization of love. The depersonalization of love is only made possible if the lover recognizes the indwelling presence of God in the person. It is only in this manner that the lover would not look at the person as an object of desire but as beloved. By looking at the other person as beloved could one fulfill the demands of his own being, which calls him to participate in the divine nature of The Creator in, with, and through his very own action. The human person, hence, becomes a steward of creation. Love summons the human person to live the spirit of koinonia (Benedict XVI, 2005), to be in communion with others as well as with the entire creation physically, psychologically, emotionally, and spiritually (Gaudium et Spes, 1965, par.49). Being created in the very image and likeness of God is a call. It is a vocation to be true to one's very identity and to the very reason behind one's existence to be a person for others, not only for ourselves. Love, hence, is a communion of being, a oneness of being. The next questions might then be, how one would love others? The issue, then, on particular vocation comes in, specifically on marriage.

\subsection{The respondents perception on love and the church concept of love}

It is presented, based on the statistical result, that the respondents do perceive love in a radical and liberal way for it opens the door for the possibility of a homosexual relationship, in which the Church is categorically firm of her position. However, the exposition of the concept of the Church on love proves that the position of the 
respondents does not contradict the Church's primary teaching on love, rather, in total harmony with it. The result displays that love for the respondents is directed not so much on the self but on others. Love for them, as an extrinsic movement, recognizes the uniqueness of (in) others. Love is accepting and respecting others not for what they have, but for who they are; it loves the person behind the man, not the externalities. Moreover, since the approach and understanding on love are in a personalistic way, it is even socially permissible for them to love the other person regardless of who and what he/she is as long as God is at the center; it is accepting and loving the entirety of the person for one recognizes God in that person. This perception of love is deeply rooted in the Catholic faith that one should unconditionally love others. Hence, there exists asymmetry, in this regard, between the position of the respondents and that of the Church.

However, while the Church and the respondents do recognize the invaluable worth of the beloved in the process of love, they tend to partway on the possibility of a homosexual relationship. The perception of the respondents clearly transcends the limitations sanctioned by gender on the issue of intimacy in the relationship between two homosexual individuals; their understanding of love might lead to a homosexual relationship. On the other hand, the Church is influential with her conviction that while love towards the person is an exercise of Christian charity and the person's participation in the divine essence, it is immoral that love might lead to the union of the same sexes. This is simply because love is an amalgamating force that should lead to the sacrament of marriage (Cf. Gen.2:24) for love's very teleology is the existence family. "Marriage and the family are ordered to the good of the spouses and to the procreation and education of children. The love of the spouses and the begetting of children create among members of the same family personal relationships and primordial responsibilities" (CCC, 1992, par. 2201). Hence, for the Church, love leads to the marital union of two heterosexual individuals, and that union generates life as a participation in the creative act of God, leading to the formation of the family. In this principle, the possibility of a homosexual relationship is a total illusion.

\subsection{Marriage as a union of complementary opposites}

The explicit position of the Church on marriage is founded in the book of Genesis, particularly the creation of man and his/her commissioning. The second story of creation mentioned that the world was prepared first by God for man to be its steward and gave him the freedom to fulfill this mandate from God. However, despite the authority that God had given to Adam and despite the richness of the world that surrounds him, there was no suitable partner (Gen.2:18) that could satiate the desire of his heart; the world cannot satisfy the inner longing of man for someone. Seeing the anguish of Adam, God created someone out of the former's rib and called it the woman. When Adam woke up, he saw the woman that God had made and bellowed, "This, at last, is bone of my bones and flesh of my flesh; this one shall be called Woman, for out of Man this one was taken" (Gen.2:23). God then commissioned them to be fruitful and subdue the earth. Here, one can see clearly that the woman, not the world, is the only created being that satisfied the inner longing of man.

The theological framework of the sacrament of matrimony lies in the original oneness of being between man and woman. The book of Genesis is reasonably clear that before Eve was created out of Adam's rib, there existed a person. The existence of Adam as a person before the creation of Eve speaks of the oneness of being between the man and the woman, and when the woman was created, this oneness of being with the man is disrupted. However, the disruption caused by the separation of man from the woman is just momentary for both of them are destined to be with each other again in the oneness of being through the sacrament of marriage. "The vocation to marriage is written in the very nature of man and woman as they came from the hand of the Creator" (CCC, 1992, par.1603). "Therefore, a man shall leave his father and mother and cleave to his wife, and they shall become one flesh" (Gen 2:24).

Moreover, though man and woman are biologically different from each other, the sacrament of marriage transcends the differences of their being and transforms them into avenues of complementariness. Therefore, the man complements the woman, and the woman completes the man. The sense of complementariness between the man and the woman points to the oneness of their being. Since there exists a complementariness of being

60 Consortia Academia Publishing (A partner of Network of Professional Researchers and Educators) 
Teaching basic theological doctrines: Reconciling the church's teaching and the perspectives of Catholic teens

between the man and the woman in marriage, both of them, despite their biological differences, are being enriched by the love that binds them as one with a joyful and a ready will (Gaudium et Spes, 1965, par.49). One can clearly see that men and women are created for each other (CCC, 1992, par.1605).

This same complementariness existing between the man and the woman leads to the fulfillment of God's mandate to be fruitful, for which both of them were commissioned. Pope Paul VI in Humanae Vitae (1969, par.9) argued that the marital union between the man and the woman should be fecund. In other words, the relationship existing between married couples should be open to the possibility, but not limited to, of life as its end. Their union should be proactive and pro-life in view of the fact that they complement each other. Marriage must generate life. "Marriage and conjugal love are by their nature ordained toward the procreation and education of children. Children are really the supreme gift of marriage and contribute in the highest degree to their parents' welfare" (Gaudium et Spes, 1965, par. 1070-1072). In other words, the oneness of being between married couples is not just a simple issue of being existentially together, but their union which speaks of the complementariness of their being should lead to procreation; the love that both married couples have with each other should bear a child, which in return could enrich both of them as parents, couples, and individuals. In this regard, marriage for the Church is not just an ordinary outcome of love but it should lead to childbearing as the very telos of that love. This is a vocation of loving God above all else in loving one's neighbor, in this context, one's husband/wife, as one loves himself, leading to the possibility of having a child as its very end.

\subsection{The respondents' perception and the church's concept of marriage}

According to the result, the respondents do have an open mindset with regard to the possibility of homosexual marriage. The mere fact that they did not restrict marriage only between man and woman, as stated in the mean score for question number eight, they are expressing their affirmative consent on homosexual marriage. For the respondents, homosexual marriage is not a possibility but a complete reality that should be accepted by many. What is crucial for them is the person and the love that unites them together. If an absolute norm restricts this bond simply because it is defined as "unnatural and evil" for some reason, then it should be condemned for it is designed not to affirm love nor liberate the person from personal isolation, but to disparage the love that two homosexual persons have with each other. In this case, this same norm denounces their sexuality - their attraction, feelings, and the way they feel and understand love based on their identity. As long as two homosexuals are genuinely in love with each other without violating the rights and dignity of others, the relationship should be recognized by the conservative institution, including the Church. After all, the Catholic faith is centered on Jesus (John Paul II, 1998), who accepts people for who and not what they are, and even not for what they have. The Catholic faith, therefore, caters not only to the spiritual needs of the people, including members of the LGBTQ+ community, but also to their temporal needs, and very much part of it is the need to love.

The respondents accept the way members of the third sex express their sexuality through love, for one could not wholeheartedly say that one respects the other if one undermines an aspect of the other. Respect is utterly accepting not only an element of the person but the entirety of his/her persona because one recognizes the invaluable dignity that God had given in that person (Benedict XVI in USCCB, 2020). Now, the norm that the Catholic Church sustains is that marriage is only proper to the heterosexual gender for it leads to the sacramental mystery of procreation. While homosexual union does not meet this standard norm, the union itself is intrinsically evil (Jung, 2001; Siker, 2006) and their very nature is disordered (CCC, 1992, par. 2358). In other words, the Church condemns homosexual relationships simply because it is not open to procreation. Though the Church recognizes that homosexuals and the like as persons imbued with dignity, the way they express their sexuality in the aspect of marriage should be contained. Here, one can see that the Church recognizes the person but condemns an aspect of the person.

Hence, in the aspect of marriage, the Church clearly disapproves of the perception of the respondents because homosexual marriage does not lead to procreation, which is the teleology of marriage. The married 
couple is called to be fruitful and affirm their love by participating in the creative act of God. Fruitfulness in the marital aspect is comprehended as participation in God's creation by being "co-creators." A relationship that does not lead to this possibility is deemed unnatural and, therefore, should be corrected.

\section{Conclusion and recommendations}

Having this position, the question now is, are the respondents still Catholics? Should they be punished for having this belief? The result of the test also shows that the respondents themselves do have a strong sense of their Catholic faith. Their belief in God is firm as well, in the precepts of the Church. Nevertheless, their understanding and the way they live out faith is unconventional. Having a positive stance on homosexual marriage leaves the respondents nursing a liberal approach to religion. They are not less Catholic for having an eccentric and seemingly uncanonical, but their approach to the faith is just a mere appropriation of the Catholic faith in modern times. In the lenses of the Church, the respondents might be having a double standard attitude with regard their identity as Catholics and their perception on homosexual marriage, hence nonpracticing ones. However, for the respondents, their notion seems to just stipulate the real examples of Jesus in accepting people the way they are.

Their notion of love, marriage, and religiosity respects and recognizes the person behind the human face; it transcends the biological makeup that restricts the existence of a person to just be what he/she is biologically be. This perception indeed creates a dualism, but more than creating ideological dispute between the conservatives and the liberals, may there be an agora and a table of negotiation wherein everybody is open for genuine dialogue and is transparent in enriching the faith and making it even more relevant in today's world. "May they be one," that is the very cry of Jesus - a cry of unity and cry of fraternal solidarity. A call that summons the faithful to have a listening heart that accepts and understands, not discriminate and isolate. The respondents' view on the topics of love, marriage, and homosexual relationship is a challenge to see the faith in a new way without losing its tradition. In a world where change is inevitable, the challenge is to revitalize the faith so that its teachings on the life of Jesus will forever be relevant.

After determining that there exists an incongruency between the notion of the respondents on marriage in relation with homosexual union and the teachings of the Church the researcher would like to propose certain recommendations that would help the Church to understand the context not only of the respondents but of all those who have similar beliefs with the respondents and for them to feel that the Church is there to accompany them in their journey.

D A Lecture on the Youth's Understanding on Homosexuality - This would be a great venue for the Church and other sector to know the position of the young in understanding not just the generalizations of sexuality but primarily the complexity of homosexuality, for it is only in understanding the context of the young could one will be able to know the proper approach to the problem and the ways in helping homosexuals.

$>$ A Program for Dialogue and Counselling — This program revolves around the concept of the Greek Agora wherein every person has a chance to express himself/herself. This would create a symbiotic space of mutual learning for the young so raise their sentiments on the topics of love, marriage, homosexual relationship, and other topics akin to their life; they might also raise practical solutions to resolve some of the issues prevalent in their stage. In this way the young would be a collaborator of the Church and other sectors of society. However, at their stage one cannot deny the fact that while there is much to learn from the young, they still need the guidance and wisdom of the adult. That is why series counselling should be conducted without imperatively imposing one's will. Because when one imposes his/her will the sense of dialogue is broken, and the dream of mutuality remains a possibility. Counselling should respect the individuality of the person and allow him/her to discover the richness of his/her existence as a person and moreover as a Catholic faithful.

62 Consortia Academia Publishing (A partner of Network of Professional Researchers and Educators) 
Teaching basic theological doctrines: Reconciling the church's teaching and the perspectives of Catholic teens

$>$ A Revisit of the Faith - This is basically the call of Pope Francis to make the faith ever relevant in the ever-changing time and context of the people especially the young. Many special synods were formed to read the signs of the times and to reevaluate the position of the Church in the modern times. In this sense, one should be open to the ever changing context of the people that one could effectively present the faith to the contemporary man without undermining where he/she is coming from - the context by which the contemporary man moves, conducts his life, and have his being.

These are some of the many possible interventions that one can think of in order to understand the young especially on matter of love, marriage, and religiosity. But one thing is certain, a program for them with a good vision of helping them would not be successful if one young will not be allowed to speak for themselves and become collaborators in forming programs for them. Listening to the young is the key behind the principle of synodality by which the pope invites the entire Church to embark upon; It is only in the spirit of synodality could the Church makes the faith ever relevant to the life of the young and in the ever-changing context of society.

\section{References}

Alpert, J. S. (2016). If you are not a liberal when you are young, you have no heart, and if you are not a conservative when old, you have no brain. The American Journal of Medicine, 129(7), 647-648. https://doi.org/10.1016/j.amjmed.2016.01.054

Aparta, D. (2015). Change is the only constant thing in this world. Retrieved from https://thoughtcatalog.com/danielle-aparta/2015/05/change-is-the-only-constant-thing-in-this-world/

Baghramian, M., Baghramian, C., \& Adam, J. (2019). Relativism. In E. N. Zalta (Ed.), The Stanford encyclopedia of philosophy. https://doi.org/10.4324/9780429343308

Benedict XVI. (2005). Deus caritas est. Retrieved from https://www.vatican.va/content/benedict-xvi/en/encyclicals/documents/hf_ben-xvi_enc_20051225_deus -caritas-est.html

Bittel, J. (2015). Climate change is affecting the way creatures interact. Retrieved from https://psmag.com/environment/climate-change-affecting-way-kinds-creatures-interact-97563

Boghossian, P. (2011). The maze of moral relativism. Retrieved from https://opinionator.blogs.nytimes.com/2011/07/24/the-maze-of-moral-relativism/

CCC. (1992). Catechism of the Catholic church. Retrieved from https://www.vatican.va/archive/ENG0015/_P85.HTM

Council of Europe. (2020). Religion and belief. Retrieved from https://www.coe.int/en/web/compass/religion-and-belief

Crossroads. (2018). The only constant in life is change. Heraclitus. Retrieved from https://crossroadsantigua.org/the-only-constant-in-life-is-change-heraclitus/

De Fide Catholica. (1870). The Vatican council. Retrieved from https://www.vaxxine.com/pjm/vaticanI.htm

Del Castillo, F. (2016). Perceptions on love of the young people: An assessment based from the love attitude scale. Assessment for Learning Within and Beyond the Classroom, 28, 339-360. https://doi.org/10.1007/978-981-10-0908-2_28

Dillard, J. (n.d.). 5 most important methods for statistical data analysis. Retrieved from https://www.bigskyassociates.com/blog/bid/356764/5-Most-Important-Methods-For-Statistical-Data-An $\underline{\text { alysis }}$

Francis. (2016). Amoris laetitia: Post-synodal apostolic exhortation on love in the family. Retrieved from https://www.vatican.va/content/francesco/en/apost_exhortations/documents/papa-francesco_esortazione -ap_20160319_amoris-laetitia.html

Gaudium et Spes. (1965). Retrieved from

https://www.vatican.va/archive/hist_councils/ii_vatican_council/documents/vat-ii_const_19651207_gau dium-et-spes_en.html

Hardgrove, A., Pells, K., Boyden, J., \& Dornan, P. (2014). Youth vulnerabilities in life course transitions. UNDP 
Human Development Report Office (pp. 1-49). Retrieved from http://hdr.undp.org/sites/default/files/hardgrove_boyden_hdr_2014.pdf

Hill, E. (1996). Creation and creator: Knowing and glorifying God. New Blackfriars, 77(907), 390-400. https://doi.org/10.1111/j.1741-2005.1996.tb01573.x

Hopkins, P., \& Unger, M. (2017). What is a subject-matter expert? The Journal of Pipeline Engineering, 16(4), 227-230.

John Paul II. (1979). Redemptor hominis. Retrieved from https://www.vatican.va/content/john-paul-ii/en/encyclicals/documents/hf_jp-ii_enc_04031979_redempt or-hominis.html

John Paul II. (1981). Familiaris consortio. Retrieved from https://www.vatican.va/content/john-paul-ii/en/apost_exhortations/documents/hf_jp-ii_exh_19811122_f amiliaris-consortio.html

John Paul II. (1994). Gratisimam sane. Retrieved from https://w2.vatican.va/content/john-paul-ii/es/letters/1994/documents/hf_jp-ii_let_02021994_families.ht $\underline{\mathrm{ml}}$

John Paul II. (1998). Fides et ratio. Retrieved from https://www.vatican.va/content/john-paul-ii/en/encyclicals/documents/hf_jp-ii_enc_14091998_fides-et$\underline{\text { ratio.html }}$

Jung, P. B. (2001). Sexual diversity and Catholicism: Toward the development of moral theology. Minnesota, MS: The Order of St. Benedict Inc.

Kelley, D. M. (1977). Why conservative churches are growing: A study in sociology of religion with a new preface for the rose edition. Mercer, GA: Mercer University Press.

King, Jr, M. L. (1952). Reinhold Niebuhr's ethical dualism. The Martin Luther King, Jr. Papers Project (pp. 141-152).

Krejcie, R. V., \& Morgan, D. W. (1970). Determining sample size for research activities. Educational and Psychological Measurement, 30(3), 607-610. https://doi.org/10.1177/001316447003000308

Lumen Gentium. (1964). Retrieved from https://www.vatican.va/archive/hist_councils/ii_vatican_council/documents/vat-ii_const_19641121_lu men-gentium_en.html

Morrow, V. (2013). Troubling transitions? Young people's experiences of growing up in poverty in rural Andhra Pradesh, India. Journal of Youth Studies, 16(1), 86-100. https://doi.org/10.1080/13676261.2012.704986

Niebuhr, R. (1930). The contribution of religion to social work. New York, NY: Columbia University Press.

Pasig Catholic College. (2018). History. Retrieved from https://www.pasigcatholic.edu.ph/history/

Paul VI. (1968). Humanae vitae. Retrieved from https://www.vatican.va/content/paul-vi/en/encyclicals/documents/hf_p-vi_enc_25071968_humanae-vita e.html

Piper, J. (1987). The pleasure of God in his creation. Retrieved from https://www.desiringgod.org/messages/the-pleasure-of-god-in-his-creation

Siker, J. S. (2006). Homosexuality and religion: An encyclopedia. Santa Barbara, CA: Greenwood Publishing Group.

St. Thomas Aquinas. (1911). Summa theologica, Vol. I Part I. New York, NY: Cosimo Classics.

Stanford. (2016). Dualism. In Stanford encyclopedia of philosophy. Retrieved from https://plato.stanford.edu/entries/dualism/

The University of Minnesota. (2020). Types of statistical tests. Retrieved from https://cyfar.org/types-statistical-tests

Trochim, W. M. (2020). Descriptive statistics. Retrieved from https://socialresearchmethods.net/kb/descriptive-statistics/

USCCB. (2020). Recognizing every person's God-given dignity. Retrieved from https://www.usccb.org/issues-and-action/human-life-and-dignity/torture/torture-is-a-moral-issue-studyguide-chapter-one.cfm

64 Consortia Academia Publishing (A partner of Network of Professional Researchers and Educators) 
Teaching basic theological doctrines: Reconciling the church's teaching and the perspectives of Catholic teens

William, D. (2003). Commitment. In multidimensional measurement of religiousness/ spirituality for use in health research: A report of the Fetzer institute/ national institute on aging working group. New York, NY: John E. Fetzer Institute. 
Cañete, J. J. O. 